\title{
Writing Life, Writing Back, and Writing Through: Saloma Miller Furlong's Why I Left the Amish: A Memoir and Bonnet Strings: An Amish Woman's Ties to Two Worlds
}

\author{
Sabrina Voelz ${ }^{1}$ \\ Post-Doctoral Lecturer and Researcher \\ Department of Modern Languages / North American Studies \\ Leuphana University \\ Lüneburg, Germany
}

\begin{abstract}
In recent years, the memoir boom has left publishers searching far and wide for new material. As part of this trend and the immense demand for anything Amish, non-professional writers have seized the opportunity to make their voices heard. While there is a wealth of scholarship on the Amish, the often trauma-filled narratives of the ex-Amish have neither been widely accessible to the public, nor the subject of much academic scrutiny until recently. This article explores the memoir, its genre conventions, and current debates. Furlong's debut memoir, Why I Left the Amish (2011), is a powerful narrative about a desperate struggle for self-determination. She breaks the silence on mental illness as well as physical and sexual abuse among the Amish while also providing readers with cultural information and alternative perspectives on Amish traditions and values. At the same time, Why I Left the Amish raises a few ethnical concerns. In the second installment to her serial memoirs, Furlong explores the challenges of beginning a new life in an unfamiliar environment and coming to terms with her trauma-filled past. Bonnet Strings: An Amish Woman's Ties to Two Worlds (2014) is a more polished memoir, in which Furlong critically reflects on her first memoir, narrates her struggle to build interpersonal relationships, as well as continues to forge her own intersectional identities.
\end{abstract}

\section{Keywords}

Ex-Amish memoir; Serial memoir; Reader response theory; Memoir boom; Scriptotherapy; Trauma; Cultural scripts; Intersectional identities; Privacy; Ethics 


\section{Introduction}

In comparison to autobiography, the memoir may seem rather simple in form and function, but upon closer inspection one may discover that a seemingly transparent life narrative is actually a rather complex work. After briefly discussing memory theory and the significance of life writing for identity creation, I will introduce Saloma Miller Furlong's serial memoirs, Why I Left the Amish: A Memoir (2011) and Bonnet Strings: An Amish Woman's Ties to Two Worlds (2014). I will then discuss the memoirist's writing style and her identities presented in her books. The frame of Why I Left the Amish is the death of Furlong's father and her agonizing decision whether to return home for his funeral 25 years later. While she is not present when her father dies, she attends his funeral, all the while reliving flashbacks of her childhood and teenage years. Multiple factors play a role in Furlong's enduring ordeal and her decision to run away from her former Amish community located in Geauga County, Ohio.

Furlong has remarked that writing and publishing her life narrative have helped her come to terms with deep-seated pain:

Even though I had been in therapy for years, I still had the need to tell my story to have my experiences acknowledged and understood by others. [...] It has been gratifying to have my readers understand and empathize with my experiences, which has allowed me to bring my healing, reconciliation, and forgiveness to another level. (Voelz 2016)

Thus, Furlong's memoirs may be viewed as "scriptotherapy," defined by Suzette Henke (1998) as "the process of writing out and writing through traumatic experience in the mode of therapeutic reenactment" (xii). Memoirists, such as Furlong, would likely agree that one of the most challenging aspects about writing memoir can be found in its implicit obligation to leave one's comfort zone to "re-experience" unpleasant or traumatic key events.

In contrast to autobiography, in which autobiographers usually record and reflect on their own achievements, memoir has become associated with the everyday lives of average people (Buss 2001; Couser 2012). Marginalized people and those who feel silenced, ignored, or misrepresented have therefore been drawn to memoir as a more accessible form of writing than autobiography: "For those muted groups, reconceiving themselves is crucial to increasing their agency in society" (Rusk 2002, 5). At the heart of agency is contestation; memoir-in contrast to the historically male-dominated autobiography - is an especially attractive form for women (Buss 2002, 3).

Although a number of ex-Amish women have written memoirs, many Amish women tend to be generally content with their lives and roles in the community (Hostetler 1993, 15; Kraybill 2001, 87; Hurst and McConnell 2010, 122). Karen Johnson-Weiner (2001) even advances the position that "in many respects Old Order Amish women have greater power and status in their church than many 'English' or non-Amish women" (231). While that may indeed be the case, scholarship should not only attend to the majority, but also freely acknowledge those with 
conflicting ideas about Amish life. Thus, "talking back," as bell hooks (1989) refers to this "moving from silence into speech" (9), is an essential part of beginning that dialogue. Not only does Furlong write for her own healing and fulfillment, but she also speaks for the marginalized Amish or ex-Amish, the sexually abused Amish teen, the "wayward" Amish runaway, and the ex-Amish memoirist.

\section{The Rise of Ex-Amish Memoirs}

Crucial for preserving their way of life, Amish communities rely on a common language, a shared heritage, and a strong values and belief system, but they also share several core values with other Americans, in particular the separation of church and state, freedom of religion, and an appreciation of hard work. Other Amish values stand in contrast to mainstream American society; the Amish eschew competition, materialism, and individualism. Amish societies prefer to rely on God, community, and family for assistance in times of need. They are encouraged to remember the acronym JOY: "Jesus first, Others in between, and Yourself last" (Kraybill 2008, 13). They refer to their complete trust in and obedience to God, as well as the "forsaking all selfishness," as Gelassenheit (Kraybill 2001, 30). Thus, it is not surprising that those who permanently leave the Amish have not in the past sought much public attention, as publically criticizing Amish ways and airing "dirty laundry" stands in stark contrast to their upbringing and beliefs they have been taught. Internalized cultural scripts are not easily forgotten or overcome. Despite such habitual reticence, and in part due to the rise of social media and self-publishing, the number of insider perspectives on the Amish that are available to larger society is growing. The quality and reliability of these publications, however, greatly varies.

Ex-Amish who do eventually want to publish memoirs through conventional channels typically have several formidable obstacles to overcome. First, they have to come to terms with the traumas associated with leaving their families and communities behind, especially as memoirists must have distance to their subject matter and be devoid of bitterness and a revengeful spirit. Second, they have to adapt to their new life and find a way to support themselves. Additionally, prospective memoirists have to acquire good writing skills and fashion their history into a compelling story so that they can secure a publisher willing to take a chance on an unknown writer. Developing these skills requires the support of others and takes timemonths if not years (Furlong 2014, 327-29). In fact, it took both Saloma Miller Furlong and Ira Wagler twenty years or more to write their life narratives and see them published. Finally, prospective memoirists have to be prepared for the potential backlash of "writing against the grain." In other words, there are personal costs associated with making the private lives of other people public (Voelz 2016).

Despite all these difficulties, the publication of memoirs by ex-Amish is increasing. A number of factors have played a role in this phenomenon. First, the growth of ex-Amish memoirs may be seen to be part of a general "memoir boom" fueled by social media's focus on the private, everyday lives of individuals. Since the 1990s, this rise of social media and memoir has 
led to an increase in voyeurism and growing interest in unknown, non-professional writers (Couser 2012). Second, a fascination with the Amish has also been increasing, as is apparent in the demand for excursions and vacations to Amish country as well as for Amish merchandise and food products (Trollinger 2012; Kraybill and Nolt 2004). The hassles of modernity have left many with a nostalgic yearning for a slower, simpler way of life. Part of that fascination includes an interest of many in gaining access to "real" Amish individuals and insider perspectives. Third, evangelical Christians who see the Amish as fellow Bible-believing Protestants are fueling the demand for literature devoid of sex and strong language. The number of Amish romance novels has soared: just one such novel was published in 2000; there were eighty in 2012 (WeaverZercher 2012, 410-11). Finally, the success of Furlong's Why I Left the Amish and Wagler's New York Times bestseller, Growing Up Amish, have paved the way for an outpouring of further life narratives by former members of Amish and other plain societies. ${ }^{2}$

\section{Memoir: Genre Considerations and Debates}

Defining memoir is a difficult task, and becoming more difficult because the borders between the various forms of life writing have become blurred (Stamant 2014, 13). However, critics generally agree that both autobiography and memoir are thematically-shaped, nonfictional, self-reflective narratives that describe and reflect on past events. Furthermore, both genres are relational in that memoirists see themselves as social beings who define their intersectional identities not only in terms of gender, age, ethnicity, class, and religion, but also in terms of their social roles and relationships to others (Buss 2001, 595; Couser 2012, 23). One major difference between autobiography and memoir, however, is that autobiography casts a writer's entire life into a fluid narrative, while the memoir is a more fragmentary form, focusing on a segment of a writer's life and the historical or cultural context in which the life was lived. As mentioned above, many contemporary memoirs deal with aspects of the everyday life of average individuals, a fact that make it an accessible or "democratic" form open to all. The autobiography, however, tends to represent a noteworthy person's final achievement. In some cases, memoirists may even concentrate more on the lives of significant others than the self. Therefore, memoir as a genre has been positioned in a continuum between the biography at one end and the autobiography at the other (Couser 2012, 20). It has also been characterized as a flexible form that blends "a number of writing practices to achieve its place as a historicized personal story, creating a style that is narrative and dramatic as well as essayistic" (Buss 2001, 596).

The majority of memoirs can be divided into two modes: the "memoir" (tout court) and the "literary memoir," a term used by Judith Barrington $(2007,109)$. For my purposes, both these modes may be grouped together as the most significant difference between them is the degree to which creativity, aesthetics, and/or voice is emphasized. Memoir falls under the umbrella term "creative non-fiction" and makes use of narrative devices that novelists may employ, such as dialogue, metaphors, flashbacks, and tension. It is often distinguished from its less-respected, 
profit-driven "popular" variant (Zinsser 1998, 5-6). Barrington (2007) underlines the "scandalous or gossipy nature" of popular memoir (109), while Becky Bradway and Doug Hess (2009) emphasize that popular memoirs lack the characteristics of creative non-fiction, as they "don't use inventive language and style, don't have a voice, and are often written by cowriters or ghostwriters" (13). Regarding cowriters, however, the difference between a ghostwriter and a true collaborator should not be neglected. In fact, due to their communal roots, ex-Amish writers may have a certain affinity to collaboration, ${ }^{3}$ so it would be imprudent to automatically equate co-written memoir with popular writing in general, and especially in the case of ex-Amish memoirs.

The word "memoir" stems from the French word "mémoire," designating memory or remembrance. The unreliability of memory and the constructive character of the act of remembering have gained much attention from literary scholars in recent years, and Susan Tridgell (2005) has underscored the uncertainty of "reconstructed rather than triumphantly recovered" memory and "its tendency to change with time" (382). Although memoir writers are not expected to display journalistic or historical objectivity, outright invention and dishonesty are still considered taboo. For the most part, memoir readers have come to tolerate minor inconsistencies or unintended oversights as intrinsic to the genre, but only if these do not affect the narrative's overall credibility or larger truth. This reader tolerance of human error in memoir may be seen as part of a post-modern understanding of memory as fallible, and of forgetting as an integral part of remembering, and even as an "unmasking of the pretention to objectivity" which is important in itself (Cline and Angier 2016,12). The mask of objectivity must be lifted not only because memory may be "poor" or "selective," but also because of the danger of partial perspective, stemming from incomplete information. Thus, the general assumption is that if objectivity in memoir is unachievable, then memoirists should avoid presenting themselves as all-knowing and simply admit their limitations where applicable.

Furlong may serve as a clear example for this point, as she adopts this practice at times, particularly when expressing traumatic memories. In Bonnet Strings, for example, the narrating I confesses that she cannot remember how her parents reacted when the narrated I moved out of her parent's home after it was finally clear that she - due to the difficulties at home - could no longer live there. In the following passage, Furlong (2014) seemingly anticipates the questions that her readers may have:

I don't remember any interactions with my family members as I moved, nor do I remember what emotions I was having. Did Mem cry? Or was she cheerful as she helped me gather my things? Was Datt there? What mood was he in? I can only speculate why my memory of this time is so full of gaps. It seems that, whenever I had conflicting emotions at that time in my life, I would somehow flick a switch like a safety valve, and turn off all feeling. These incidents remain the holes in my memory. ${ }^{4}(143)$ 
This "unmasking of the pretention to objectivity" by memoirists has led some to expand the gray area between fiction and non-fiction. In her New York Times' best-selling book, The Art of Memoir, Mary Karr (2015) lists the most commonly used "liberties" in memoir writing. These include changing names of characters or places; masking the details of "someone's appearance for the sake of their privacy" (25); including information unavailable to the subject in the text; using an episode to represent a larger period of time; re-creating dialogue; and shaping a narrative or excluding information as well as recounting scenes heard about but not witnessed (25). Yet, a clear agreement as to the extent that liberties can and should be used in memoir writing has not been reached.

G. Thomas Couser (2012), for one, warns against the blurred boundaries between novel and memoir, as when, for example, a memoirist tries to recreate long passages of dialogue verbatim from memory, even when writing about situations that happened many years past (78). Thus, in contrast to Karr (2015), he prefers "summary" to "scene" in other words, description over the creation of "the illusion of observing experience quite directly, as it unfolds - the way the audience in a theater observes events as they are performed by actors" (70). For him, it seems more productive to limit the reader's involvement in the narrative than to jeopardize readerly trust. Even so, he suggests that memoir is infused with both "presumed factuality" (mimetic reality from the vantage of hindsight that is believed to be factual) and "artfulness" (15). In creating a self-reflective, medial representation of the past, the memoirist artfully — but not too artfully_recounts episodes from his or her life. For historians or sociologists, the more "conservative" approach to memoir writing may appear preferable as memoir tends to be read as eye-witness testimony or historical evidence as was done, for instance, with Elie Wiesel's monumental memoir Night, which chronicles his traumatic ordeal during the Holocaust. For literary scholars and some general readers concerned with formative, non-fictional experience artfully narrated, the "literary" variant of memoir may be more satisfying than the form Couser favors.

Some critics in the field of life writing also advance reader response theory, according to which readers co-construct the meaning of the texts (Rusk 2002, 2; Smith 1987, 7). As Wolfgang Iser (1978) postulates, "Aesthetic response is [...] to be analyzed in terms of a dialectic relationship between text, reader, and their interaction. It is called aesthetic response because, although it is brought about by the text, it brings into play the imaginative and perceptive faculties of the reader, in order to make him adjust and even differentiate his own focus" (x). This approach allows for, as Smith and Watson (2001) stress, the discourse to shift from "verifying knowledge to observing processes of communicative exchange and understanding" (17). The assumption is that readers desire more than a distraction or entertaining self-referential story, but that they also seek a sincerely told, non-fictional narrative with which they can identify with on some level, and from which they can learn something about themselves and the world.

The potential challenge presented by reader response theory as I see it for Amish studies is to overcome the general fear that some readers may read a memoir, such as Furlong's Why I 
Left the Amish, and make negative conclusions about the Amish. This is an understandable concern. After all, the negotiation between the Amish and the dominant society that takes place on fundamental issues necessary for the preserving Amish ways, such as school attendance or the use of buggies, depends on the willingness of governments at the local, state, and federal levels to make compromises with Amish communities. If this closed society is viewed negatively, then future compromises whatever they might be could certainly prove more challenging. In the case of Elie Wiesel's Night mentioned above, historians found dozens upon dozens of eye-witness reports that support most of the book's insights. Only then did it come to be viewed as one book representative of Jewish Holocaust experience. Inasmuch as this article is the first in-depth study published on an ex-Amish memoir, it still remains to be seen which aspects - if any-can be seen as representational.

The Amish are not the only ethnic minority that has shared the concern about depictions of their group in the media. One action that the African Americans or Asian Americans, for example, have taken to off-set negative representations is to write and publish their own literary works. Amish voices are increasingly finding their way into publications for larger audiences. In 2014, Herald Press began publishing insider perspectives in the series "Plainspoken: Real-Life Stories of Amish and Mennonites," books also certainly worthy of scholarly inquiry. Loren Beachy's (2014) charmingly funny book, Chasing the Amish Dream: My Life as a Young Amish Bachelor, opened the series. As diverse as Amish communities are, however, not all Amish societies may approve of such measures, as they might encourage even more tourism to Amish country.

Finally, before taking a closer look at Furlong's memoirs, I would like to conclude this short overview of the scholarly discourse around memoir by briefly drawing attention to the writer/producer of life writing and the complexity of the narrative situation. In this regard, Sidonie Smith and Julia Watson (2001) advocate distinguishing between the various functions performed by the memoirist who exists beyond the confines of the narrative he or she is producing and is both observer or investigator and object of study or experiencer. These four distinct, but interrelated "roles" can be defined as follows: First, the "real' or historical 'I," "situated in a certain time and location "unknown and unknowable by readers" (72); second, the "narrating 'I"" or "the 'I' who tells the autobiographical narrative" (72); third, the "narrated 'I"" or person who experienced the events and life (73); and fourth, the "ideological ' $I$ "' or the self that is "historically and culturally situated" (76-77). Neither a book nor series of books can fully reveal a person's complete being. Still, life writing is generally thought to be a place of identity construction through the acts of writing and rewriting of consciously chosen episodes from a life and the fashioning of them into a coherent narrative (Brockmeier 2001, 456; Smith and Watson 2001, 38-41). 


\section{Trauma in Why I Left the Amish-A Web of Interrelated Factors}

Writers who produce a memoir as personal as Why I Left the Amish must form an intimate bond with readers and establish themselves as trustworthy, credible authors. One method for doing so is the inclusion of personal photos. In the center pages of Why I Left the Amish, readers will find photos of the narrated I as a child, teen, and adult; Furlong's family; and Amish building and farms. Not only do the photos serve as evidence that Furlong was Amish, but they-along with the back matter of the book-give us insight into the work's implied readership. Obviously a book dealing with topics such as sexual, physical, and mental abuse in Amish society will not resonate much with readers within plain Anabaptist communities as Ira Wagler's Growing Up Amish seems to do. ${ }^{5}$ The photos in Furlong's book, its secular publisher (Michigan State University Press), and the short informational texts on the Amish included in the back matter all indicate that the book is intended for a wider public. ${ }^{6} \mathrm{Be}$ that as it may, the narrating I in the memoir still seeks a genuine dialogue with her mother, hoping at one point that she would "share more of her inner life" and the "mysterious time" of her childhood (Furlong 2011, 180).

Why I Left the Amish is filled with trauma, resulting from a web of interrelated factors that make life for Furlong in her Amish environment impossible. Although there are numerous definitions of trauma, for the purposes of concision, I will use Neil Thompson and Mary Walsh's (2010) delineation, according to which trauma can be defined as some kind of shocking or upsetting "experiences [that] produce feelings of anomie, powerlessness, frustration, vulnerability and confusion which, in turn, are likely to produce a destabilization of meaning and therefore create the need for the re-establishment of meaning" (282). In Furlong's memoir, the narrating I can be seen attempting to "re-establish meaning" and to overcome feelings of helplessness, shame, and guilt through speaking openly about the taboo topic of abuse among the Amish as well as the structures within Amish society that both impede action against wrongdoers and work against helping the abused. Reacting to her father's brutal beating of her sister Susan, Furlong conveys her own feelings of vulnerability: "I cried too, feeling helpless and trapped by Datt's violence. When he came after someone, there was no fighting back - he was physically strong, but when he was in one of his rages, he was as strong as a bull, and just as wild" (140). The narrated I serves both as a victim of and witness to abuse.

Several passages, testify to the failure of Amish leaders and non-Amish social agencies in mainstream society to come to the aid of Amish children and youth, even when their assistance was actively sought after (139-41). Due to her father's violent furies, the narrated I seeks intervention from a social worker (150). Unable to gain the necessary permission of an adult relative, she receives word that nothing can be done to help her for nine months until she reaches the age of twenty-one (153). Disappointed and angry that her mother refuses outside assistance, the narrated I hits rock bottom and contemplates suicide (154). Certainly, much has changed since then, but even today "the Amish are reluctant to go to outsiders because of the 
cost, because of a lack of trust, and because they desire to handle these issues inside the community" (Hurd 2015, 247). ${ }^{8}$

One factor attributing to the family's lower standing in the community is the mental illness of the narrated I's father, Sim. Depressed at times, he is unable to provide consistently for his family and held accountable for their poverty as a result. According to Furlong, her community employed this double bind for their own purposes:

At some point, I [Furlong] realized our family was serving a purpose within the community - we were used as an example of what could go wrong if one was lazy, didn't help oneself, or didn't properly adhere to the Amish ways. This allowed other families to be gut oh tzene (well regarded), while we provided the contrasting bad example. (29-30)

Just as poverty is the fault of the poor, blame is also placed on the victim of violence. Thus, although the community may disdain Furlong's father with his family as examples of selfinflicted failure and poverty, Sim is given greater status than the wife and family he abuses and cannot adequately provide for. In a crucial passage, Sim's sins are publically acknowledged by the bishop, who exclaims: "If the wife and children would be more obedient, then Sim wouldn't have this problem. Since that is the case, I will take his confession sitting down, instead of having him get on his knees, if no one has any objection to that" (141). The implied openness to objections is rhetorical since, according to Furlong, "women in the church were not allowed to oppose anything. They had to tell their husbands if they disagreed with the policies of the church, and then it was the men's duty to relay that information to the bishop" (141). Reluctantly, the ideological I gives into social pressure, remains silent, and yields to the authority of the bishop's looming presence.

The episode recounted in the previous paragraph seems quite in accordance with Amish cultural scripts which tend to view abuse as a spiritual problem for which the sinner must seek repentance and publicly confess. Afterwards, the sin is to be spoken of no more, for "the Amish are constantly warned by their leaders against gossip and criticism. This may encourage some people to accept a wrong rather than deal with it" (Hurd 2015, 248). However, at this point, Furlong can no longer stomach her father's repeated acts of violence and the "coerced" forgiveness of her father, so the narrated I makes the decision to leave even if this means she would "go straight to Hell" (154), a statement underscoring the desperation of her situation.

As the preceding discussion should already have indicated, Why I Left the Amish notably illustrates the complexity of abuse and intersectionality of identities. In the memoir, factors of age, health, gender, ethnicity — in this case almost indistinguishable from religion - and class are interlinked to the detriment of Furlong and the rest of her family, pushed to the margins of society. Toy Lisa Mitchell (2015) explains how intersection functions:

The intersection of these cultural identities influences and shapes one's realities because of their dynamic pervasiveness in one's private and public spheres. Publically, these 
cultural identities are situated within societal hierarchies of power that in turn are embedded within institutions. Privately or individually, one's identity is developed in concert with these cultural identities which entails the way they are viewed and valued by others as well as the self. (29)

In addition to the physical violence that Furlong and all her siblings experience, the narrating I recounts the mental trauma she endured at the hands of her older brother. One such incident involves "an experiment to see how long it would take for rabbits to starve to death" (91), an experiment of a sadistic 10-year-old boy to exhibit his power over life and death. It is a cruel act that caused Furlong to be terrified of her older brother. As a result of this paralyzing fear and the multiple beatings he gave her, she reluctantly participates in her own molestation four years later when she was eleven and her brother Joe fourteen (77-94). Disturbing is her mother's refusal to take action as the narrated I finds the courage to tell her "protector" about the sexual abuse: 'I couldn't lie. 'Joe—-bothered me. In the blackberry patch.' Mem got quiet for a moment; then she asked 'Well, why did you let him?' Mem's words struck me like a whip” (86).

The violence inflicted by Mem's words is especially visible not in the narrated I's feeling she had been struck by a whip, but in the narrating I's reflection on this moment. The narrating I surely sees, and surely wants her readers to see, that this accusatory question says more about Mem than about herself, revealing a mother complicit to abuse. But even over two decades later, the narrating I is still scarred by the deep wound suffered by the narrated I in that moment and still blames herself for giving "consent out of fear" (87). The narrated I's involvement in incest is influenced by the ideological I that, in the words of James Hurd, "demands that children submit to their father, girls [...] to boys, women to men, and all [...] to church leadership" (245). Children internalize these cultural scripts at an early age. The ideological I is at work not only in the situation mentioned above, but in several instances when the narrated I wants to but fails to speak out or rebel against church practices and gender roles.

Due to the violence and trauma described in her book, Furlong's memoir may be uncomfortable for readers and perhaps even unrepresentative of Amish life. It is nonetheless important for her to bear witness to an otherwise unspeakable and seemingly invisible "truth," not only for her own healing, but for those who have had similar experiences - in Amish societies and elsewhere - as well as for those who idealize the Amish as a "model minority" (Cong 1994).

\section{Literary Influences and Ethical Concerns}

Furlong's first memoir is written in the literary vein. Not only does she use flashbacks characteristic of trauma narratives instead of adhering to chronological order as the majority of memoirs does, but each chapter also receives its own title and is equipped with epigraphs from a variety of sources, emphasizing a more thematic arrangement than might be expected of a writer avoiding the gray areas between fact and fiction. Furlong also uses montage to include letters she 
has written to others into the text (2011, 2-4, 4-5); by doing so, the narrating I intimately invites readers into the narrative, especially since these letters were written to her mother and her father shortly before his passing.

The narrating I employs metaphors, just as a fiction writer would. Thus, the door of the family home barred to keep intruders out does not make Furlong feel secure; rather, "the barred door made me feel trapped. Danger didn't just come from outside our house-it lurked in every corner" (11). After making plans plan to leave in a way that would not endanger her "safety or well-being" (155), Furlong flees to Vermont, where she intends to begin a new life. The memoir concludes an image of a butterfly presented as both an object of beauty and a metaphor for freedom:

Back on that day when I was shedding my Amish clothing and having my hair cut and buying my first English clothing, it was as if I was transforming from a chrysalis to a butterfly. I felt like a caterpillar in my dark cocoon when I was in the community, and my subsequent freedom gave me wings - flying, as in my dream, from one adventure to another. (181)

Through her writing, the memoirist has shown that she has become a determiner of her fate and is able to secure her own freedom. Why I Left the Amish can consequently be read as a comingof-age story.

Furlong's memoir is poignantly written, yet there are a few limitations that should be mentioned. Although dialogues written from memory are certainly legitimate, readers may feel uneasy about a few overly long dialogues (e.g. 22-25, 50-52, 91-94), dialogues that would have appeared more credible had they included a disclaimer about imperfect memory. Such a disclaimer would be issued by the narrating I, who also seems unhelpfully absent in other passages: personally, for example, I missed the presence of the narrating I in a passage that relates a conversation Furlong has with her son Tim, who asks basic questions about Amish clothes, the use of technology, and church rules at the funeral (54-56). I was left wondering why the narrated I had not previously talked with her son about basic Amish beliefs or if she had maintained silence about her heritage. Without metacommentary, the conversation seems somewhat contrived as a pretense to work in basic facts about the Amish for her readers.

Yet these are relatively small moments of writerly clumsiness. A more significant criticism pertains to the narrating I's revelations that might be hurtful or embarrassing to others. Respecting the privacy of others is one of the cardinal rules of memoir writing (Barrington 113114; Couser 103-105; Smith and Watson 241). While some leeway may be extended to indiscretions that reveal the sordid deeds of perpetrators, the speculative outing of Joe as a likely victim of sexual abuse is of central concern (65). Even though this speculation is in itself plausible, and might partially explain his violent behavior and sexual deviance, it does not appear that the narrating I informed him in advance of her intent to publicly air such private details, nor 
does she do much in the text to justify making his intimate private life public, details the Amish community in which he still resides might not have known about. The risks of such "outing" of others are why Karr (2015) advocates focusing on oneself in memoir as opposed to speculating about other people's motives (26).

Furlong also makes some hurtful remarks about her sister which may be likewise problematic regarding privacy concerns, and which also disrupt the readerly identification with the narrating I:

In fact, Sarah did what I vowed I would never do, even when I still was Amish—she married her second cousin. Our mother was a first cousin to John's mother. When I first found out that they were related, I laughed and said, "Sarah, you had the whole world open to you, and you came back and married your second cousin?" I thought she would laugh with me, but she didn't. I have learned not to talk about the issue at all anymore because of her sensitivity to it. (68)

This passage reveals that the narrating I's lacks distance to her subject matter and sounds rather bitter; it is a passage that the publisher's editorial staff should have cautioned against or simply deleted. ${ }^{9}$ The narrating I also exposes the incest between Joe and all the sisters, not just herself: "He molested all of us, but Katherine was the most vulnerable. And she is the only one who got pregnant. And I still think it was he who got her pregnant" (92). There is a lesson to be learned from "collateral damage" as Couser (2012) refers to the result of committing "serious ethical wrongs" (91).

At this point, it may be useful to ask the question whether I as a scholar am adding to that "collateral damage," by highlighting problematic passages in Furlong's memoir. And perhaps to some extent I am. From a utilitarian point of view, I hope by doing so to increase awareness about privacy issues especially among potential memoirists, so that they can learn from Furlong's unintended oversights. In an unpublished interview I did with Ira Wagler, in Leola, Pennsylvania, on August 25, 2012, he remarked that his publishers insisted that he give advanced copies of Growing up Amish to family members to read before sending the book to print. He followed that recommendation: "All my siblings and their spouses have read it. I was just so amazed because they were all supportive. Some are Mennonite, some are Amish, and some are all over the place. There are things they would have preferred me not to mention, but none of them questioned any detail." It was sound advice that Wagler received. It may not be easy to face up to family members, but it is an essential part of memoir writing to allow those people mentioned in the book, especially those close to the writer, access to the memoir before publication. They should know what is being said about them and have a chance to respond. Concern about the representation is a topic to which Furlong returns in her second memoir, Bonnet Strings. 


\section{Bonnet Strings as Serial Memoir}

Bonnet Strings can be read as a memoir on its own or as an installment of a serial memoir. In an increasingly post-literate world, the growing interest in serial memoir can partially be contributed to the shift toward shorter narratives (Stamant 2014, 6), e.g. blogs as well as flash and twitter fiction. In addition to creating a loyal and returning reader (or customer) base, serial memoir offers the advantage that the development of a subject's identities can be viewed over time, as a reflection of the time in which it was written. Writers of serial memoir mostly can and often do re-visit and re-evaluate personal identity and memories of the same events, while linking them to new revelations and life episodes: "The existence of serial memoir increases the textual space available to counter-memory and witnessing, allowing for repeated acts of uncovering constructs of selfhood and multiple negotiations of identity/-ies" consistent with postmodern theory (Stamant 2014, 5). In multi-book projects, writers explore episodes from a life without having to show or discover the "cohesive, consistent "interior self" of autobiography (5). Through its reflection and reinterpretation of events and memory, serial memoir, therefore, evokes a greater feeling of "truthfulness" than autobiography, due to "increasing skepticism about both the possibility of a cohesive self and the ability either to know or tell the 'truth' about such a self' in the modern age (Gunzenhauser 2001, 75).

In the introduction to Bonnet Strings $(2014,15)$, the narrating I admits that both of her sisters cut off contact with her after reading Why I Left the Amish and that it took some time before communication was possible. She explains the "Amish mindset" (15) as a means to shed light on Sarah's and her own behavior (15-17). By calling attention to her strong-willed nature that just not does fit in with Amish beliefs and values (11), Furlong focuses on herself instead of completely rejecting Amish gender roles. The reflecting narrating I of Bonnet Strings also concedes that she is unsure whether her experiences of sexual abuse represent "the norm" in Amish communities (14), a clarification that would have been helpful had it already been made in Why I Left the Amish and which might have made that book more palatable to those concerned about the reputation and representation of the Amish. Furlong's discussion of these points show how serial memoirs can function: Bonnet Strings allows the narrating I a place to revisit the shortcomings of Why I Left the Amish while introducing new themes - that of finding love and coming to terms with her Amish heritage. Albeit the narrating I's reflection on memoir writing is largely restricted to the introduction, her commentary is a welcome addition to Bonnet Strings and an improvement over Why I Left the Amish. Traditionalists might disagree with me here, but I propose that metacommentary need not be confined to an introduction.

It is important to note at this point that the opportunities of serial memoir are not merely formal consequences of the genre. It takes significant courage for a writer to publically admit weakness. In this way, the ex-Amish writer ironically exhibits humility, a core Amish value (Kraybill 2001, 40-43). ${ }^{10}$ Furlong's greater reflectiveness in Bonnet Strings, her humility, and 
perhaps her greater integration of some of the positive Amish values she grew up with clearly indicate her growing maturity as a writer.

In Bonnet Strings, the narrating I continues to use a literary style, and she again uses the montage of personal letters, and the combination of summary and scene, but the number of overly long passages of dialogue has been reduced. ${ }^{11}$ An innovative inclusion is the presence of her husband's perspective in three chapters. It is fitting that this memoir should include David Furlong's point-of-view as it is written overall in the style of a romance novel. ${ }^{12}$ His words ring with neither anger nor bitterness, even after Linda-Furlong's self-given moniker while living in Vermont near David Furlong - abruptly abandons him to return "home" after a van-full of Amish show up to exert pressure on her. Ultimately, David Furlong's patience and enduring love prevail, even after the narrated I publically and unequivocally rejects him (2014, 177-180). Eventually, the narrated I realizes that being a "premature, old maid" will not fulfill her (2014, 212). She musters up the courage and strength to fight her battle with bulimia and openly leaves her community, but this time she parts on good terms with those who matter.

The idea of memoir writing as scriptotherapy, which I alluded to at the beginning of this paper, may make memoir sound as if it is entirely about the past, and about the memoirists who need to work through that past and to move on. But the moving on is crucial here, and memory is not only about the past, it is significant for the present and future. I hope my essay has indicated the importance of Furlong's memoir in helping Furlong, her readers, and the Amish community move forward. As Sue Campbell (2014) proposes, "Remembering for the future allows us to highlight positive and forward looking notions of taking responsibility" (137). Thus, Furlong's Why I Left the Amish may, for example, be useful as a case study for those in the health and social services, inasmuch as it shows the intersectionality of identities, the complexity of dealing with mental illness and abuse in an Amish community as well as the difficulty of challenging cultural scripts. For all of us, including those within the culture, Why I Left the Amish may serve as a kind of cautionary tale; awareness is a first step toward prevention. If it can additionally be better understood why Amish youth leave their communities, then perhaps some of these issues may be addressed and may even lead to positive changes. It is, of course, up to Amish societies to determine what should be done - if anything — about such insights, but they may be worth considering. Furlong's writing is not without its flaws, but despite some overly long dialogues as well as a few troubling violations of the privacy and hurtful speculations that should not have been shared, Why I Left the Amish is a remarkable book that gives a voice to previously "invisible" people in Amish societies. In Bonnet Strings, the narrating I attains more distance to her subject matter, develops as a writer, and pens a more balanced memoir. After re-examining her first installment of the series, Furlong continues the story of the prodigal daughter who is welcomed back into the fold, achieves some standing, but then secures her lasting freedom with her husband, David Furlong, outside the community. 


\section{Endnotes}

${ }^{1}$ Contact information: Sabrina Voelz, Leuphana Universität Lüneburg, ZeMoS Abteilung Englisch / Nordamerikastudien Scharnhorststr. 1. 21335 Lüneburg; +49 (0)4131 6772664; voelz@uni.leuphana.de

${ }^{2}$ See, for example, Eash and Eash (2014), Eicher (2013), Gingerich (2014), Schwartz (2012), and Mast (2016). This list is not exhaustive and does not include, for instance, self-published exAmish memoirs.

${ }^{3}$ Especially in cases of unequal power distribution, Smith and Watson $(2001,68)$ problematize the concept of collaboration in life writing.

${ }^{4}$ Italics are used in the original.

${ }^{5}$ Although Wagler's blog is full of personal and family photos, his memoir is not. Respectful of Amish ways, he selected a Christian publisher and does not reflect on potential alienating practices. Wagler does criticize Amish ways of life, e.g. the Amish's devout adherence to tradition and hierarchy as well as the absence of true dialogue about the faith, but he also shows the beauty of Amish life, a topic not dealt with in Why I Left the Amish.

${ }^{6}$ Topics include: the naming process, the relationship of the Amish and Mennonites as well as terms for outsiders.

${ }^{7}$ All passages refer to Why I Left the Amish unless otherwise stated.

${ }^{8}$ Today, the need for the training of health personnel, social workers, and police officer to deal with plain Anabaptists has been recognized. Apart from attending workshops and continuing education programs, practitioners in these sectors have access to material and scholarship that foster cultural understanding. See, for instance, Cates (2014) or Purnell (2014).

${ }^{9}$ In Bonnet Strings, Furlong thanks her editorial team for helping to find strategies to reduce the provocative nature of certain parts of her narrative, "while still staying true to the story" (329).

${ }^{10}$ In contrast to the idea of autobiography as a place for self-aggrandizement and preserving one's achievements for posterity, Patrick Madden (2014, 226-27) views humility as an essential characteristic of memoir writing today.

${ }^{11}$ In Bonnet Strings, Furlong incorporates a number of excerpts from letters that she had written to her friend, Barbara, who kept all her correspondence. In an interview with the Courier Tribune (March 15, 2014), the memoirist has revealed the importance of that exchange: "'I felt like I could write things to her in the letters that I could not write in a diary, for risk of it being found,' she said. 'Years later, Barbara gave me all those letters back and when I was writing the book, I put them all in order chronologically."” 
${ }^{12}$ Similar to a number of popular "Amish" mystery novels, such as Barbara Workinger's In Dutch Again, Bonnet Strings concludes with recipes for Mem's white bread, sticky buns, pie crust, peach pie, and apple pie, alluding to the intended readership.

\section{References}

Barrington, Judith. 2007. "Writing the Memoir." Pp. 109-115 in The Handbook of Creative Writing, edited by Steven Earnshaw. Edinburgh, UK: Edinburgh University Press.

Beachy, Loren. 2014. Chasing the Amish Dream: My Life as a Young Amish Bachelor. Harrisonburg, VA: Herald Press.

Bradway, Becky, and Doug Hess. 2009. Creating Nonfiction: A Guide and Anthology. Boston, MA: Bedford/St. Martin's Press.

Brockmeier, Jens. 2001. "Identity.” Pp. 455-56 in Encyclopedia of Life Writing, Volume I, edited by Margaretta Jolly. London, UK: Fitzroy Dearborn.

Buss, Helen. 2001. “Memoir.” Pp. 595-97 in Encyclopedia of Life Writing, Volume II, edited by Margaretta Jolly. London, UK: Fitzroy Dearborn.

Buss, Helen. 2002. Repossessing the World: Reading Memoirs by Contemporary Women. Waterloo, ON: Wilfrid Lauerier University Press.

Campbell, Sue. 2014. Our Faithfulness to the Past: The Ethics and Politics of Memory. Edited by Christine Koggel and Rockney Jacobsen. Oxford, UK: Oxford University Press. https://doi.org/10.1093/acprof:oso/9780199376933.001.0001

Cates, James. 2014. Serving the Amish: A Cultural Guide for Professional. Baltimore, MD: John Hopkins University Press.

Cline, Sally, and Carole Angier. 2010. The Arvon Book of Life Writing: Writing Biography, Autobiography and Memoir. London, UK: Methuen Drama.

Cong, Dachang. 1994. "The Roots of Amish Popularity in Contemporary U.S.A.” Journal of American Culture 17(1):59-66. https://doi.org/10.1111/j.1542-734X.1994.00059.x

Courier Tribune. March 15, 2014. "Former Amish woman shares story of leaving." Retrieved October 2016 (http://www.courier-tribune.com/news/former-amish-woman-sharesstory-leaving)

Couser, G. Thomas. 2012. Memoir: An Introduction. Oxford, UK: Oxford University Press. https://doi.org/10.1093/acprof:osobl/9780199826902.001.0001

Eash, Irene, and Ora Eash. 2014. Plain Faith. Grand Rapids, MI: Zondervan. 
Eicher, Jerry. 2013. My Amish Childhood. Eugene, OR: Harvest House Publishers.

Furlong, Saloma Miller. 2014. Bonnet Strings: An Amish Woman's Ties to Two Worlds. Harrisonburg, VA: Herald Press.

Furlong, Saloma Miller. 2011. Why I Left the Amish: A Memoir. East Lansing, MI: Michigan State University Press.

Gingerich, Emma. 2014. Runaway Amish Girl: The Great Escape. Aledo, TX: Progressive Rising Phoenix Press.

Gunzenhausen, Bonnie J. 2001. “Autobiography.” Pp. 75-77 in Encyclopedia of Life Writing, Volume I, edited by Margaretta Jolly. London, UK: Fitzroy Dearborn.

Henke, Suzette. 1998. Shattered Subjects: Trauma and Testimony in Women's Life-Writing. New York, NY: St. Martins's Press.

hooks, bell. ${ }^{1}$ 1989. Talking Back-Thinking Feminist, Thinking Black. Boston, MA: South End Press.

Hostetler, John. 1993. Amish Society. Baltimore; MD: John Hopkins University Press.

Hurd, James. 2015. “The Amish Gemeinschaft Community: Pro-Woman?” Pp. 239-249 in Religion and Men's Violence against Women, edited by Andy Johnson. New York, NY: Springer. https://doi.org/10.1007/978-1-4939-2266-6_15

Hurst, Charles, and David McConnell. 2010. An Amish Paradox: Diversity and Change in the World's Largest Amish Community. Baltimore; MD: John Hopkins University Press.

Iser, Wolfgang. 1978. The Act of Reading: A Theory of Aesthetic Response. Baltimore, MD: Johns Hopkins University Press.

Johnson-Weiner, Karen. 2001. "The Role of Women in Old Order Amish, Beachy Amish, and Fellowship Churches.” Mennonite Quarterly Review 75(2):231-56.

Karr, Mary. 2015. The Art of Memoir. New York, NY: Harper Collins.

Kraybill, Donald. 2008. The Amish of Lancaster County. Mechanicsburg, PA: Stackpole Books.

Kraybill, Donald. 2001. The Riddle of Amish Culture. Baltimore, MD: John Hopkins University Press.

\footnotetext{
${ }^{1}$ The author does not capitalize her name.
} 
Kraybill, Donald, and Steven Nolt. 2004. Amish Enterprise: From Plows to Profits. Baltimore, MD: John Hopkins University Press.

Luckhurst, Roger. 2008. The Trauma Question. London, UK: Routledge.

Madden, Patrick. 2014. "The 'New' Memoir.” Pp. 222-235 in The Cambridge Companion to Autobiography, edited by Maria Dibattista and Emily Wittman. Cambridge, UK: Cambridge University Press. https://doi.org/10.1017/CCO9781139235686.020

Mast, Johnny, and Shawn Smucker. 2016. Break Away Amish: Growing Up with the Bergholz Beard Cutters. Harrisonburg, VA: Herald Press.

Mitchell, Toy Lisa. 2015. "Making Visible the Invisible: Cultural Scripts that Inform Relationships among African American Women.” Pp. 29-43 in Routledge International Handbook of Race, Class, and Gender, edited by Shirley Jackson. London, UK: Routledge.

Purnell, Larry. 2014. Guide to Culturally Competent Health Care. Philadelphia, PA: F.A. Davis Company.

Rusk, Lauren. 2002. The Life Writing of Otherness: Woolf, Baldwin, Kingston, and Winterson. New York NY: Routledge.

Schwartz, Mary Kaufman. 2012. Coming into Focus: From an Amish Childhood to a Journey of Many Choices. Mustang OK: Tate Publishing.

Smith, Sidonie. 1987. A Poetics of Women's Autobiography: Marginality and the Fictions of Self-Representation. Bloomington, IN: Indiana University Press.

Smith, Sidonie, and Julia Watson. 2001. Reading Autobiography: A Guide for Interpreting Life Narratives. Minneapolis, MN: University of Minnesota Press.

Stamant, Nicole. 2014. Serial Memoir: Archiving American Lives. Houndmills, UK: Palgrave Macmillian. https://doi.org/10.1057/9781137410337

Thompson, Neil, and Mary Walsh. 2010. “The Existential Basis of Trauma.” Journal of Social Work Practice 24(4): 377-89. https://doi.org/10.1080/02650531003638163

Tridgell, Susan. 2005. “Memory.” Pp. 381-384 in Encyclopedia of Women's Autobiography. Vol. II. Westport, CT: Greenwood.

Trollinger, Susan. 2012. Selling the Amish: The Tourism of Nostalgia. Baltimore, MD: John Hopkins University Press. 
Voelz, Sabrina. 2016. “Art Meets Life: An Interview with Ex-Amish Author Saloma Miller Furlong," in American Studies Blog. Retrived Oct. 2016 (http://blog.asjournal.org/artmeets-life-interview-ex-amish-author-saloma-miller-furlong/).

Wagler, Ira. 2011. Growing Up Amish. Carol Stream, IL: Tyndale.

Weaver-Zercher, Valerie. 2012. "Tracing the Backstory of Amish Romance Novels." Mennonite Quarterly Review 86(4):409-36.

Zinsser, William (ed.). 1998. Inventing the Truth: The Art and Craft of Memoir. Boston, MA: Mariner Books. 